\title{
Demographic, Clinical and Serological Characteristics of the Patients with Sjögren's Syndrome: A Tertiary Clinic Experience
}

\author{
Sjögren Sendromlu Hastaların Demografik, Klinik ve Serolojik Özellikleri: Üçüncü \\ Basamak Deneyimi
}

(D) Nurdan Yılmaz, (D) Osman Demir*

Tokat Gaziosmanpaşa University Faculty of Medicine, Department of Physical Medicine and Rehabilitation, Tokat, Turkey

*Tokat Gaziosmanpaşa University Faculty of Medicine, Department of Biostatistics, Tokat, Turkey

\section{Abstract}

Objective: This study aimed to evaluate the demographic, clinical and serological characteristics of patients with Sjögren's syndrome (SS). Materials and Methods: Forty-nine patients with SS admitted to our outpatient clinic between January 2015 and April 2019 were included in this study. Patients were evaluated retrospectively in terms of age, gender and primary/secondary SS state; concomitant diseases with secondary SS, the presence of other related chronic diseases, minor salivary gland biopsy and autoantibody evaluation results were recorded. Results: The mean age of the 49 patients (46 females, 3 males) included in the study was $48.39 \pm 11.45$ years (minimum: 18, maximum: 81). Female/male ratio was 15.3/1. Thirty-four (69.4\%) of the patients had primary SS, while $15(30.6 \%)$ patients were diagnosed as secondary SS. The most common symptom at the time of diagnosis was dry eye (98\%) and dry mouth (92\%). Antinuclear antibody positivity was found to be $40.8 \%$ and rheumatoid factor positivity as $28.6 \%$. Anti-SS-A and anti-SS-B was positive in $46.9 \%$ and $26.5 \%$ of the patients, respectively. Conclusion: SS is characterised by heterogeneity of clinical manifestations, serological markers and symptoms. The symptom severity and variety of the patients are also affected by the other concomitant rheumatic diseases.

Keywords: Sjögren's syndrome, sicca symptoms, primary Sjögren's syndrome, secondary Sjögren's syndrome, auto-antibodies

\section{Öz}

Amaç: Bu çalışmada kliniğimize başvuran Sjögren sendromu (SS) tanılı hastalarımızın demografik, klinik ve serolojik özelliklerin değerlendirmesi amaçlandı.

Gereç ve Yöntem: Çalışmaya Ocak 2015 ve Nisan 2019 tarihleri arasında polikliniğimize başvuran SS tanılı 49 hasta dahil edildi. Hastaların geriye dönük olarak yaş, cinsiyet, SS'nin primer/sekonder olma durumu; sekonder ise hangi hastalığa eşlik ettiği, ilişkili olabilecek diğer kronik hastalıkların varlığı, tükürük bezi biyopsisi ve otoantikor değerlendirme sonuçları kaydedildi.

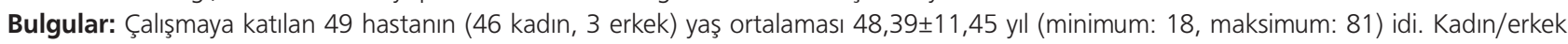
oranı 15,3/1 idi. Hastaların 34'ü $(\% 69,4)$ primer SS tanısı alırken, $15{ }^{\prime} \mathrm{i}(\% 30,6)$ sekonder SS idi. En yaygın başvuru yakınması kuru göz $(\% 98)$ ve kuru ağız (\%92) idi. Çalışmamızda anti-nükleer antikorlar pozitifliği \%40,8 olarak saptanırken, romatoid faktör pozitifliği \%28,6 idi. Hastaların $\% 46,9^{\prime}$ unda Anti-SS-A; \%26,5'inde ise anti-SS-B pozitifti.

Sonuç: SS'de klinik bulgular, serolojik belirteçler ve semptomlar heterojendir. Hastaların semptom şiddeti ve çeşitliliği diğer eşlik eden romatizmal hastalıklardan da etkilenir.

Anahtar kelimeler: Sjögren sendromu, sikka semptomları, primer Sjögren sendromu, sekonder Sjögren sendromu, otoantikorlar

\section{Introduction}

Sjögren's syndrome (SS) is a chronic autoimmune disease; which causes dry eye and dry mouth (sicca symptoms) due to lymphocytic infiltration in the exocrine glands (1). Although sicca symptoms are the most common clinical findings; there are different clinical manifestations in SS (1).
In SS except lacrimal and salivary glands; other exocrine glands, lungs, kidneys and blood vessels may also been involved. The presence of the disease itself, is defined as "primary" SS (pSS); while in the presence of another concomitant autoimmune disease, the "secondary" SS (sSS) term is used. The most common accompanying diseases in patients with SS are rheumatoid arthritis (RA), systemic lupus erythematosus (SLE),

Address for Correspondence/Yazışma Adresi: Nurdan Yılmaz MD, Tokat Gaziosmanpaşa University Faculty of Medicine, Department of Physical Medicine and Rehabilitation, Tokat, Turkey

Phone: +90 3562129500 E-mail: nurdanyilmazdr@hotmail.com ORCID ID: orcid.org/0000-0001-5758-6792

Received/Geliş Tarihi: 31.05.2019 Accepted/Kabul Tarihi: 01.08.2019

${ }^{\circ}$ Copyright 2020 by the Turkish Osteoporosis Society / Turkish Journal of Osteoporosis published by Galenos Publishing House 
scleroderma, mixed connective tissue disease (MCTD), primary biliary cirrhosis (PBC), myositis, vasculitis, thyroiditis, chronic active hepatitis, mixed cryoglobulinemia. The disease is more common in women than men (9/1), most commonly seen in the $4^{\text {th }}$ and $5^{\text {th }}$ decades of life (2). However, it can be observed in adolescents and young adults (2). In a study of 837 women aged between 18-90; the prevalence of pSS was found to be $0.8 \%(3)$.

Among the autoimmune diseases, SS is associated with the highest risk of lymphoma. Five to ten percent of the patients will have a B cell lymphoma; mostly a low-grade type developing from mucosa-associated lymphoid tissue $(4,5)$. Increased risk of developing lymphoma is the most important complication of SS and it is the most important factor affecting mortality rate in these patients (6).

In SS; clinical findings can vary from mild glandular manifestations to a wide range of symptoms; including vasculitis, glomerulonephritis, neuropathies and even lymphomas. There may be a pre diagnosis period of 8 to 10 years, most of which is accompanied by non-specific clinical findings (7). Early and accurate diagnosis of SS will prevent development of many complications associated with this disease. In this study, by the demographic, clinical and serological evaluations of the patients with the diagnosis of SS; we aimed to increase the data on SS, which has low clinical awareness among the patients and physicians.

\section{Materials and Methods}

The approval of Tokat Gaziosmanpaşa University Faculty of Medicine Ethics Committee was obtained for our study (approval number: 16.04.2019/19-KAEK-117). Forty-nine patients (46 females, 3 males; mean age $48.39 \pm 11.45$ years) who were clinically diagnosed with SS; between January 2015 and April 2019; were included in the study. The data of the patients were evaluated retrospectively from the electronic health records in the hospital database. Therefore, informed consent form could not be obtained from the patients. The clinical diagnosis of SS is based on the American College of Rheumatology Classification Criteria for SS (at least 2 of the 3 criteria are required for diagnosis) (8). Those not fulfilling the criteria were excluded from the study. Serology screening for hepatitis B, hepatitis C and HIV was done in all patients and only those with negative serology for these viral agents were included in the study. Patients with radiotherapy to the head and neck region, sarcoidosis, amyloidosis, graft-versus-host disease, lgG4-related disease history and those with a history of drug using leading to sicca-like symptoms were excluded from the study. Histopathology results of the minor salivary gland biopsy from the lower lip were noted. Schirmer's test was used as the objective evidence for ocular involvement. Commercial ELISA kits (Euroimmun, Lubeck, Germany) were used for detection of rheumatoid factor (RF), anti- cyclic citrullinated peptide (anti-CCP), anti-nuclear antibody (ANA), anti-double stranded DNA antibody, anti-Sjögren's syndromerelated antigen $A$ (Ro/SS-A), anti-Sjögren's-syndrome-related antigen B (La/SS-B), anti-histidyl transfer RNA synthetase and anti-topoisomerase I (anti-Scl 70) 70. The results of each test exceeding their own thresholds were considered to be positive. Clinical presentations including glandular and extraglandular manifestations; demographic features including age, gender; serological profile and others were noted.

We assessed the clinical outcomes of the patients in terms of sicca symptoms, joint symptoms and systemic involvement at the last recorded follow up visit. Major systemic involvement was defined as any significant involvements of musculoskeletal, renal, cardiovascular, gastrointestinal and neurological systems. The study adhered to the principles of the Helsinki Declaration.

\section{Statistical Analysis}

IBM SPSS version 19.0 software was used for data analysis (IBM SPSS Statistics 19, Somers, New York). Descriptive statistics were given as number (n), percent (\%), mean and standard deviation. A $p$ value of $<0.05$ was considered to be statistically significant.

\section{Results}

The mean age of 49 patients ( 46 female, 3 male) included in the study was $48.39 \pm 11.45$ years [minimum (min): 18 , maximum (max): 81]. Female/male ratio was 15.3/1. Thirty four (69.4\%) of the patients were pSS; fifteen (30.6\%) patients were diagnosed as sSS. The distribution of the concomitant rheumatic diseases in patients with sSS is given in Table 1. All patients with sSS were female. The most common subjective presenting feature at the time of the diagnosis was dry eye (98\%) and dry mouth (92\%). Minor salivary gland biopsy was found positive in 43 (87.8\%) patients. Arthralgia was seen in 37 (75.5\%) patients; while the number of the patients with chronic arthritis was 10 (20.4\%). Two of the three patients with Raynaud phenomenon, had concomitant scleroderma; one patient had MCTD. Of the

Table 1. Distribution of the concomitant rheumatic diseases in patients with secondary Sjögren's syndrome and the thyroid pathologies in all patients

\begin{tabular}{|c|c|c|}
\hline Variables & $\mathbf{n}$ & $\%$ \\
\hline \multicolumn{3}{|l|}{ Rheumatic diseases } \\
\hline SLE & 4 & 8.2 \\
\hline MCTD & 4 & 8.2 \\
\hline RA & 3 & 6.1 \\
\hline Scleroderma & 2 & 4.1 \\
\hline FMF & 2 & 4.1 \\
\hline \multicolumn{3}{|l|}{ Thyroid pathologies } \\
\hline Hashimato thyroiditis & 4 & 8.2 \\
\hline Multinodular goiter & 3 & 6.1 \\
\hline Thyroid papillary cancer & 1 & 2.0 \\
\hline
\end{tabular}


10 patients with chronic arthritis; three had RA, one had MCTD and one had SLE. The remaining five patients were diagnosed as pSS.

Eight patients (16.3\%) had thyroid pathologies. The distribution of the thyroid pathologies in all patients is in Table 1. The patient with thyroid papillary cancer was also diagnosed with RA and PBC.

Two patients with renal involvement were diagnosed with pSS One of the patients with renal involvement had tubulointerstitial nephritis; while the other one had renal tubular acidosis. Two of the patients had pericardial effusion; one of these patients also had a diagnosis of RA, while the other was diagnosed with pSS. Six patients (12.2\%) had neurological involvement. In four of the patients with neurological involvement; vasculitic lesions were detected in the central nervous system, two patients had transverse myelitis. Serological characteristics of the patients are shown in Table 2. In four (66.7\%) of the patients with neurological involvement, ANA was positive. However, only one patient with neurological involvement was also diagnosed with SLE; the other five patients were diagnosed with pSS. Two patients with positive anti-Scl 70 were diagnosed with scleroderma.

\section{Discussion}

In our study, 34 of the patients were diagnosed with pSS; while 15 patients were diagnosed with sSS. The mean age of our patients was $48.39 \pm 11.45$ years (min:18, max:81). The female/male ratio of the patients was $15.3 / 1$. Compared to the literature, the mean age of our patients was lower and the female/male ratio was higher (9).

SS is characterized by a heterogeneity of clinical manifestations, serological markers and symptoms. In SS, the incidence of extraglandular systemic symptoms is about one third. The symptom severity and variety of the patients is also affected by the concomitant rheumatic diseases. In patients with SS, typically the lacrimal and salivary glands are involved. It is known that patients often present with complaints of dry eye and dry mouth. Skin, lung, heart, gastrointestinal system,

Table 2. Serological characteristics of the patients with Sjögren's syndrome

\begin{tabular}{|l|l|l|}
\hline ANA & Positive/Negative & $20(40.8) / 29(59.2)$ \\
\hline Anti-dsDNA & Positive/Negative & $2(4.1) / 47(95.9)$ \\
\hline RF & Positive/Negative & $14(28.6) / 35(71.4)$ \\
\hline Anti-CCP & Positive/Negative & $2(4.1) / 47(95.9)$ \\
\hline Anti Ro/SS A & Positive/Negative & $23(46.9) / 26(53.1)$ \\
\hline Anti La/SS B & Positive/Negative & $13(26.5) / 36(73.5)$ \\
\hline Anti-Jo-1 & Positive/Negative & $1(2) / 48(98)$ \\
\hline Anti-Scl 70 & Positive/Negative & $2(4.1) / 47(95.9)$ \\
\hline
\end{tabular}

Data are shown as $n$ (\%). ANA: Antinuclear antibody, Anti-dsDNA: Anti-double stranded DNA antibody, RF: Rheumatoid factor, Anti-CCP: Anti-cyclic citrullinated peptide, Anti Ro/SS A: Anti-Sjögren's syndrome related antigen A, Anti-La/SS B: Anti-Sjögren's-syndrome-related antigen B, anti-JO-1: Anti-histidyl transfer RNA synthetase, Anti-Scl 70: Anti-topoisomerase I central and peripheral nervous system, musculoskeletal system and kidneys can also been involved by SS $(9,10)$.

The most common rheumatic diseases associated with sSS are RA and SLE (11). Familial Mediterranean fever (FMF) and SS co-occurrence were reported as case reports in the literature $(12,13)$. Three $(6.1 \%)$ of our patients with sSS had RA, four $(8.2 \%)$ with SLE, four (8.2\%) with MCTD, two (4.1\%) with scleroderma and two (4.1\%) with FMF. Both of the patients with FMF were followed up with FMF for years. The clinic of SS was established over the time in these patients.

The musculoskeletal system findings of the SS include arthralgia, mostly non-erosive arthritis and sometimes myositis accompanied by elevation of muscle enzymes, myalgia and tenosynovitis which can lead to Jaccoud arthropathy (14).

The most common symptoms of the patients included in our study were dry eye and dry mouth; three quarters of the patients had arthralgia and approximately one-fifth of the patients had arthritis. The symptoms of arthritis and arthralgia were prominent in our patients with concomitant RA (7). Systemic involvement in SS is well known; however, obvious cardiac manifestations are extremely rare although clinically silent involvements are fairly common on echocardiography (15). Two (4.1\%) of our patients had pericardiac effusion due to cardiac involvement; one of our patients with cardiac involvement was sSS (with RA); the other patient was pSS. Renal involvement in SS is not rare. The most common renal disease is tubulointerstitial nephritis. Renal tubular acidosis may develop in these patients (16). In three retrospective studies about overt renal involvement in pSS showed that renal involvement was seen in $5 \%$ and $4.3 \%$ of the patients, respectively $(17,18)$. In our study, two (4.1\%) patients were diagnosed with renal involvement; one patient was diagnosed as interstitial nephritis and one patient had renal tubular acidosis. Both of the patients with renal involvement were diagnosed with pSS.

Raynaud's phenomenon can be seen in one third of the cases with pSS (19). García-Carrasco et al. (20) found the frequency of Raynaud's phenomenon to be $13 \%$ in a study with 320 pSS patients and it was showed that joint involvement, skin vasculitis and serological findings were more common in the Raynaud phenomenon group. In our study, three (6.1\%) patients had Raynaud phenomenon; two of the patients had concomitant scleroderma; one patient had MCTD. The frequency of Raynaud's phenomenon in our study group was lower than the literature (20).

Peripheral sensory or motor-sensory neuropathy can be seen at a frequency of $10-20 \%$ in pSS. Central nervous system involvement findings such as epilepsy and transverse myelitis have also been reported (21-23). Neurological involvement ratio was $12.2 \%$ in our study group. Our results were consistent with the literature (21-23). In four of the six patients with neurological involvement, vasculitic lesions were detected in the central nervous system; two patients had transverse myelitis. In four of these six patients, ANA was positive. One of these four patients had SLE. Particular attention should be paid to the development 
of neurological symptoms in patients with SS who are positive for ANA autoantibody.

Autoantibodies are frequently found positive in SS. ANA positivity is 55-97\%; RF positivity is $36-74 \%$ in SS. Anti-CCP positivity is $3-10 \%$. There are anti-Ro/SS-A (50-70\%) and antiLa/SS-B (25-40\%) autoantibodies against the ribonucleoprotein antigen (24). The SS-B autoantibody is more specific, but less sensitive than the SS-A autoantibody. SS-A autoantibody is also found positive in other autoimmune diseases (25). In our study, ANA positivity was found to be $40.8 \%$ and RF positivity was $28.6 \%$. Anti-SS-A positivity was $46.9 \%$ in our patients. In $26.5 \%$ of the cases, anti-SS-B was positive. Our data were compatible with the literature.

The main superiority of our study is that this is the first study evaluating the demographic, clinical and serological characteristics of patients with SS without primary-secondary discrimination. Thus, data on this disease in which there is a diagnostic delay of 8-10 years, will be increased and this study will contribute to the increase of patient-physician awareness to SS.

\section{Study Limitations}

Because of the retrospective design of our study, it is possible that some glandular and extraglandular findings have not been reported. Since it is a single-center study, the number of the patients is limited. Therefore, our results may not reflect the whole community. Long-term prospective studies are needed to determine the increased risk of malignancy in SS.

\section{Conclusion}

SS is characterized by a heterogeneity of clinical manifestations, serological markers, and symptoms. In SS, the incidence of extraglandular systemic symptoms is approximately onethird. The symptom severity and variety of the patient is also affected by accompanying rheumatic diseases. Although the most common symptom is sicca symptoms, there is a need for prospective studies about this disease, which has a wide symptomatology ranging from severe neurological involvement to lymphomas.

\section{Ethics}

Ethics Committee Approval: The approval of Tokat Gaziosmanpaşa University Faculty of Medicine Ethics Committee was obtained for our study (approval number: 16.04.2019/19KAEK-117).

Informed Consent: Informed consent form could not be obtained from the patients.

Peer-review: Externally peer-reviewed.

\section{Authorship Contributions}

Surgical and Medical Practices: N.Y., Concept: N.Y., O.D., Design: N.Y., O.D., Data Collection or Processing: N.Y., Analysis or Interpretation: O.D., Literature Search: N.Y., O.D., Writing: N.Y., O.D.
Conflict of Interest: No conflict of interest was declared by the authors.

Financial Disclosure: The authors declared that this study received no financial support.

\section{References}

1. Ramos-Casals M, Tzioufas AG, Font J. Primary Sjögren's syndrome: new clinical and therapeutic concepts. Ann Rheum Dis 2005;64:347-54.

2. Mavragani CP, Moutsopoulos HM. The geoepidemiology of Sjögren's syndrome. Autoimmun Rev 2010;9:A305-10.

3. Dafni UG, Tzioufas AG, Staikos P, Skopouli FN, Moutsopoulos HM. Prevalence of Sjögren's syndrome in a closed rural community. Ann Rheum Dis 1997;56:521-5.

4. Nocturne G. [Sjögren's syndrome update: Clinical and therapeutic aspects]. Rev Med Interne 2019;40:433-9.

5. Johnsen SJ, Brun JG, Goransson LG, Smastuen MC, Johannesen $T B$, Haldorsen K, et al. Risk of non-Hodgkin's lymphoma in primary Sjogren's syndrome: a population-based study. Arthritis Care Res (Hoboken) 2013;65:816-21.

6. Nocturne G, Pontarini E, Bombardieri M, Mariette X. Lymphomas complicating primary Sjögren's syndrome: from autoimmunity to lymphoma. Rheumatology (Oxford) 2019;kez052. [Epub ahead of print] doi: 10.1093/rheumatology/kez052

7. Kamalı S, Kasapoğlu E, Çefle A, Sayarlıoğlu M, Öcal L, Gül A, et al. Primer Sjögren Sendromlu 35 Hastanın Klinik ve Laboratuar Özellikleri: İstanbul Tıp Fakültesi Romatoloji Bilim Dalı Tecrübesi. İst Tip Fak Mecmuası 2004;67:2:104-8.

8. Shiboski SC, Shiboski CH, Criswell L, Baer A, Challacombe $\mathrm{S}$, Lanfranchi $\mathrm{H}$, et al. American College of Rheumatology classification criteria for Sjögren's syndrome: a data-driven, expert consensus approach in the Sjögren's International Collaborative Clinical Alliance cohort. Arthritis Care Res (Hoboken) 2012;64:47587.

9. Qin B, Wang J, Yang Z, Yang M, Ma N, Huang F, et al. Epidemiology of primary Sjögren's syndrome: a systematic review and metaanalysis. Ann Rheum Dis 2015;74:1983-9.

10. Sandhya P, Jeyaseelan L, Scofield RH, Danda D. Clinical Characteristics and Outcome of Primary Sjogren's Syndrome: A Large Asian Indian Cohort. Open Rheumatol J 2015;9:36-45.

11. Alani H, Henty JR, Thompson NL, Jury E, Ciurtin C. Systematic review and meta-analysis of the epidemiology of polyautoimmunity in Sjögren's syndrome (secondary Sjögren's syndrome) focusing on autoimmune rheumatic diseases. Scand I Rheumatol 2018;47:14154.

12. Dörtbaş F, Garip $Y$, Güler T, Karci AA. Coexistence of Familial Mediterranean Fever With Ankylosing Spondylitis and Sjogren's Syndrome: A Rare Occurrence. Arch Rheumatol 2015;31:87-90.

13. Tanaka M, Migita K, Miyashita T, Maeda Y, Nakamura M, Komori A, et al. Coexistence of familial Mediterranean fever and Sjögren's syndrome in a Japanese patient. Clin Exp Rheumatol 2007;25:792.

14. Romos-Casals M, Pilar BZ, Raphaèle S, Hendrika B, Simon J B, Thomas $D$, et al. Characterization of systemic disease in primary Sjögren's syndrome: EULAR-SS Task Force recommendations for articular, cutaneous, pulmonary and renal involvements. Rheumatology (Oxford) 2017;56:1245.

15. Vassiliou VA, Moyssakis I, Boki KA, Moutsopoulos HM. Is the heart affected in primary Sjögren's syndrome? An echocardiographic study. Clin Exp Rheumatol 2008;26:109-12.

16. Evans R, Zdebik A, Ciurtin C, Walsh SB. Renal involvement in primary Sjögren's syndrome. Rheumatology (Oxford) 2015;54:1541-8.

17. Ramos-Casals M, Solans R, Rosas J, Camps MT, Gil A, Del PinoMontes J, et al. Primary Sjögren syndrome in Spain: clinical and immunologic expression in 1010 patients. Medicine (Baltimore) 2008;87:210-9.

18. Ramos-Casals M, Brito-Zerón P, Solans R, Camps MT, Casanovas A, Sopeña B, et al. Systemic involvement in primary Sjogren's syndrome evaluated by the EULAR-SS disease activity index: analysis of 921 Spanish patients (GEAS-SS Registry). Rheumatology (Oxford) 2014;53:321-31. 
19. Corominas H, Ortiz-Santamaría V, Castellví I, Moreno M, Morlà $\mathrm{R}$, Clavaguera $\mathrm{T}$, et al. Nailfold capillaroscopic findings in primary Sjögren's syndrome with and without Raynaud's phenomenon and/or positive anti-SSA/Ro and anti-SSB/La antibodies. Rheumatol Int 2016;36:365-9.

20. García-Carrasco M, Sisó A, Ramos-Casals M, Rosas J, de la Red G, Gil V, et al. Raynaud's phenomenon in primary Sjögren's syndrome Prevalence and clinical characteristics in a series of 320 patients. J Rheumatol 2002;29:726-30.

21. Lafitte C, Amoura Z, Cacoub P, Pradat-Diehl P, Picq C, Salachas F et al. Neurological complications of primary Sjögren's syndrome. Neurol 2001;248:577-84.
22. Barendregt PJ, van den Bent MJ, van Raaij-van den Aarssen VJ, van den Meiracker $\mathrm{AH}$, Vecht $\mathrm{CJ}$, van der Heijde $\mathrm{GL}$, et al.Involvement of the peripheral nervous system in primary Sjögren's syndrome. Ann Rheum Dis 2001;60:876-81.

23. Moreira I, Teixeira F, Martins Silva A, Vasconcelos C, Farinha $F$, Santos $E$. Frequent involvement of central nervous system in primary Sjögren syndrome. Rheumatol Int 2015;35:289-94.

24. Fayyaz A, Kurien BT, Scofield RH. Autoantibodies in Sjögren's Syndrome. Rheum Dis Clin North Am 2016;42:419-34.

25. Shen L, Suresh L. Autoantibodies, detection methods and panels for diagnosis of Sjögren's syndrome. Clin Immunol 2017;182:24-9. 